\title{
Article \\ Reliability Analysis of Rainwater Harvesting Tanks for Irrigation Use in Greenhouse Agriculture
}

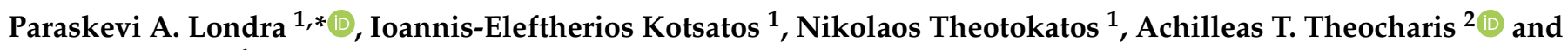 \\ Nicholas Dercas ${ }^{1}$ \\ 1 Laboratory of Agricultural Hydraulics, Department of Natural Resources Management and Agricultural \\ Engineering, School of Environment \& Agricultural Engineering, Agricultural University of Athens, \\ 75 Iera Odos Street, 11855 Athens, Greece; stud615026@aua.gr (I.-E.K.); stud615031@aua.gr (N.T.); \\ ndercas1@aua.gr (N.D.) \\ 2 General Directorate of Food, Hellenic Ministry of Rural Development and Food, 2 Acharnon Street, \\ 10176 Athens, Greece; atheocharis@minagric.gr \\ * Correspondence: v.londra@aua.gr; Tel.: +30-210-529-4069
}

Citation: Londra, P.A.; Kotsatos, I.-E.; Theotokatos, N.; Theocharis, A.T.; Dercas, N. Reliability Analysis of Rainwater Harvesting Tanks for Irrigation Use in Greenhouse Agriculture. Hydrology 2021, 8, 132. https://doi.org/10.3390/

hydrology 8030132

Academic Editor: Vasilis Kanakoudis

Received: 4 August 2021

Accepted: 30 August 2021

Published: 2 September 2021

Publisher's Note: MDPI stays neutral with regard to jurisdictional claims in published maps and institutional affiliations.

Copyright: (c) 2021 by the authors. Licensee MDPI, Basel, Switzerland. This article is an open access article distributed under the terms and conditions of the Creative Commons Attribution (CC BY) license (https:// creativecommons.org/licenses/by/ $4.0 /)$.

\begin{abstract}
Rainwater harvesting is an ancient water management practice that has been used to cover potable and non-potable water needs. In recent years, this practice is adopted as a promising alternative and sustainable source of water to meet irrigation needs in agriculture in arid and semiarid regions. In the present study, a daily water balance model was applied to investigate the size of rainwater tanks for irrigation use in greenhouse begonia and tomato cultivation in two regions of Greece with significant greenhouse areas. For the application of the water balance model, daily rainfall depth values of a 12-year time series (2008-2020) from representative rainfall stations of the study areas were used, as well as the daily water needs of the crops. The greenhouse roof was assumed to be the water collection area of the rainwater harvesting system with values ranging from 1000 to $10,000 \mathrm{~m}^{2}$. The analysis of the results showed that in the case of the begonia crop, the covered tanks ranged from 100 to $200 \mathrm{~m}^{3}$ per $1000 \mathrm{~m}^{2}$ greenhouse area with a reliability coefficient that ranged from 65 to $72 \%$, respectively, to meet the water needs of plants. Further increase of the reliability coefficient was carried out with disproportionately large volumes of tanks. In the case of the tomato crop, covered tank volumes ranged from 100 to $290 \mathrm{~m}^{3}$ per $1000 \mathrm{~m}^{2}$ of greenhouse area, and had a reliability coefficient of $90 \%$ to $100 \%$, respectively, while uncovered tanks had a maximum reliability coefficient of $91 \%$ for a critical tank volume of $177 \mathrm{~m}^{3}$ per $1000 \mathrm{~m}^{2}$ of greenhouse area and decreased for any further increase of tank volume.
\end{abstract}

Keywords: rainwater tank sizing; irrigation; daily water balance model; tomato; begonia; reliability

\section{Introduction}

Rainwater harvesting $(\mathrm{RWH})$ is an ancient water management practice, which was adopted mainly in arid and semi-arid areas of the world as a method for conservation, storage and distribution of fresh water for potable and non-potable use [1-4].

Although the use of RWH systems has been abandoned or reduced in the last century in recent years, in many parts of the world, there has been a renewed interest in rainwater collection techniques, as a sustainable source of water to meet domestic, irrigation and livestock water needs. This is related to the pressures on existing water resources by rising water demands due to climate variability, urbanization, and growing population, as well as increased food production [1,3]. In addition, the role of rainwater harvesting systems is important in flood mitigation [3].

Besides the extensive research on RWH systems for domestic use [4,5], many countries adopt strategies for promoting the use of RWH systems in agriculture [6]. Velasco-Munoz et al. [7] performed an analysis of global research on RWH for agricultural irrigation for the last twenty years. They concluded that research efforts must be increased to gain greater 
knowledge on the capacity of rainwater harvesting systems to cover irrigation needs in different farming types. They pointed out that the greenhouse agriculture type has a very low level of adoption of the RWH technique, although it has a huge potential to harvest rainwater with a low level of investment [7]. Singh et al. [8], in their study in the Ludhiana district (India), with a mean annual rainfall $781.5 \mathrm{~mm}$, concluded that a tank of $125 \mathrm{~m}^{3}$ per $560 \mathrm{~m}^{2}$ greenhouse roof area could meet $60 \%$ of the irrigation needs of the sweet pepper crop. Boyaci and Kartal [9] investigated the storage capacity of rainwater tanks to meet the irrigation needs of tomato crops cultivated in heated and unheated greenhouses in Kırşehir province (Turkey) with annual rainfall $388.3 \mathrm{~mm}$. The results of their study indicated that $61.49 \%$ of irrigation needs in heated and $47.74 \%$ in unheated greenhouses could be met by rainwater harvesting tanks with a capacity of $0.21 \mathrm{~m}^{3} / \mathrm{m}^{2}$ in unheated and $0.30 \mathrm{~m}^{3} / \mathrm{m}^{2}$ in a heated greenhouse.

In Greece, with agriculture being the main consumer of water for irrigation purposes, approximately $85 \%$ of the annual water consumption [10], and increased pressure on water resources in many areas, the construction and use of rainwater tanks is an alternative and sustainable solution for finding water for agriculture. The greenhouse area covers approximately 6200 ha [11], while the RWH technique adoption is at low levels and there is no research on tank sizing and harvesting potential.

The main region of RWH tank use is the island of Crete, where greenhouses cover 2000 ha [11]. To facilitate the use of RWH tanks, their construction is allowed in all areas of Crete, provided that they will use only the runoff water of installed greenhouses or building facilities and only for the irrigation of the same greenhouses. More specific, according to the legislation on the imposition of restrictive measures on the surface water systems of the catchments of Crete, if the storage volume of the rain tank is up to $500 \mathrm{~m}^{3}$ per $3000 \mathrm{~m}^{2}$ of a greenhouse, no special permit for the installation of the tank is required [12].

To determine the size of the rainwater tank, daily water balance models [5,13-21] or probabilistic models [22-25] have been applied. However, the capacity of rainwater tanks is strongly affected by several local variables, such as local rainfall, the water collection areas, and water demand, and cannot be standardized [5,21,26-28].

The aim of this study is the reliability analysis of rainwater harvesting tanks that are used to meet the water needs of vegetable (tomato) and ornamental (begonia) crops cultivated in greenhouses in two regions of Greece with both significant greenhouse areas and water shortage. The sizing of covered and uncovered rainwater tanks was performed by applying a daily water balance model using daily rainfall data, greenhouse roof as water collection area, water needs of plants, and evaporation data.

\section{Materials and Methods}

\subsection{Study Areas}

In Greece, $97 \%$ of the total greenhouse areas are vegetables, and $3 \%$ are flower and ornamental plants [9]. Two study areas were selected, based on greenhouse agriculture development.

In Figure 1, the distribution of lands covered by greenhouse vegetables and flower/ornamental plants, among the administrative regions of Greece, is presented (data processed from HELSTAT [11]). As shown in Figure 1a, the referred in lands under greenhouse vegetables in Western Greece and Crete regions are leading with 34.8 and 30.2\%, respectively, followed by Peloponnesus and Central Macedonia with 10 and $8.4 \%$, respectively. The percentages for the other regions are less than $17 \%$. On the other hand, with regards to lands covered by greenhouse ornamental plants, Attica is leading with $32 \%$, followed by Crete, Central Macedonia, Eastern Macedonia and Thrace, and Thessaly with $16.4,15.4,12.2$, and $10.9 \%$, respectively (Figure 1a). The percentages for the other regions are $13 \%$. Based on the aforementioned distribution, the study areas selected were Crete and Attica, which presented high percentages of lands covered by greenhouse vegetables and ornamental plants, respectively. 


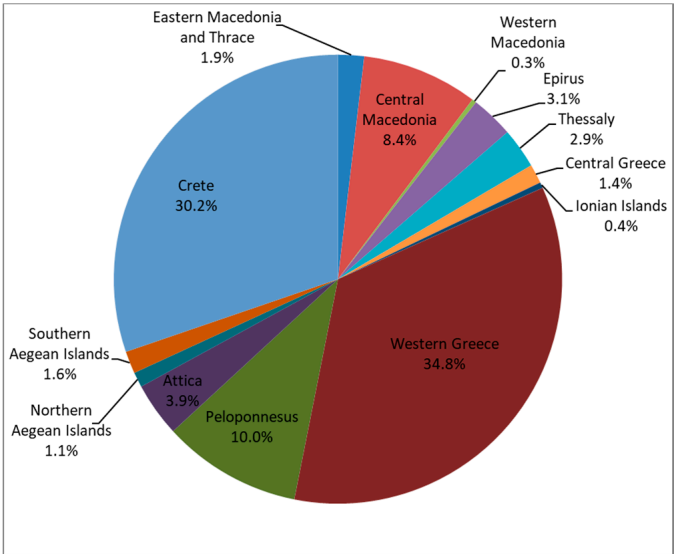

(a)

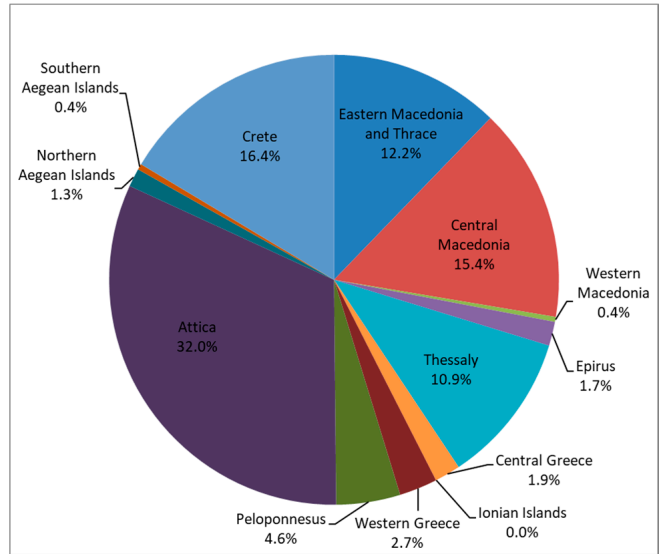

(b)

Figure 1. Distribution of lands covered by greenhouse (a) vegetables and (b) flower/ornamental plants in the administrative regions of Greece (data processed from HELSTAT [11]).

\subsection{Climate Type and Rainfall Data}

Greece is located in the southeastern part of Europe, between the 34 and 42 parallel $\mathrm{N}$., and 19 to $28 \mathrm{E}$. The climate in Greece is typically Mediterranean. That broadly means that there is a cold and rainy season lasting from the mid of October until the end of March and a warm and non-rain season lasting from April until September. There are also extended periods of sunshine throughout most of the year. During the first season, the coldest months are January and February, when the mean minimum temperature, on average ranges between 5 and $10{ }^{\circ} \mathrm{C}$ near the coast and $0-5{ }^{\circ} \mathrm{C}$ over mainland areas. During the second season, the warmest months are the summer months (June to August), and the warmest period is the last ten-day period of July and the first one of August when the mean maximum temperature ranges between 29 and $35^{\circ} \mathrm{C}$ [29].

Within the Mediterranean climate frame, due to the influence of topography, a variety of climate subtypes are found in several regions of Greece. Thus, both the dry climate of Attiki and generally of East Greece (Aegean islands coasts included), and the wet one of North and West Greece are encountered. Study areas of Athens and Ierapetra, are located in eastern Greece (Figure 2) and belong to the dry Mediterranean subtype [29].

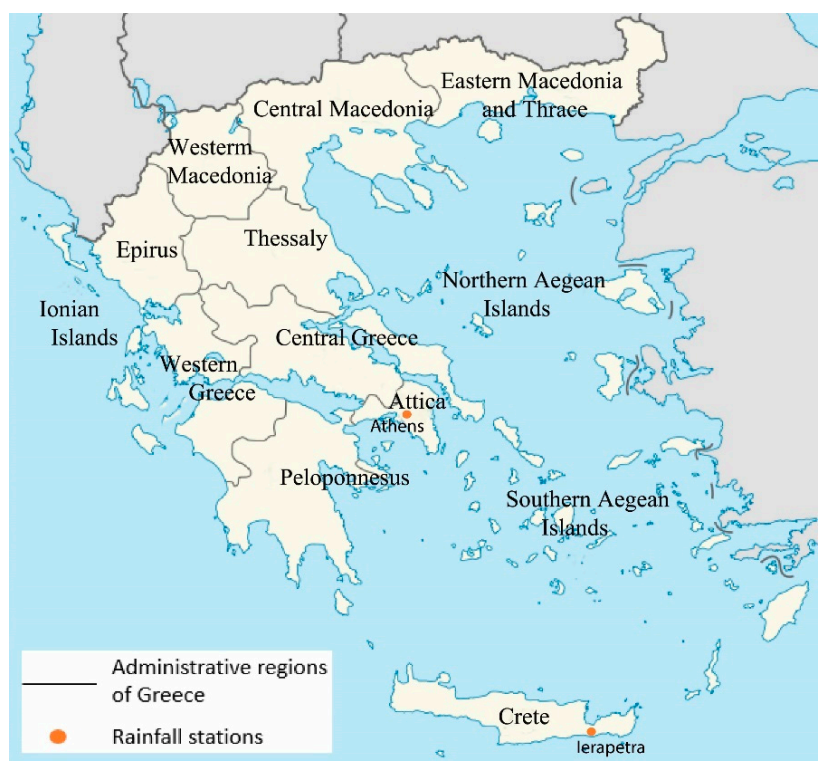

Figure 2. Rainfall stations in the study areas of Ierapetra (Crete, Greece) and Athens (Attica, Greece). 
For the present study purposes, two representative rainfall stations, one from each of the studied areas where the RWH tanks will be installed, were selected based on daily rainfall data availability and time series completeness (Figure 2). The daily rainfall data used for sizing the RWH tanks were obtained from the National Observatory of Athens database (https: / / www.meteo.gr (accessed on 10 December 2020)) regarding the time period 2008-2020. This period (12 years) exceeds the minimum length of rainfall record used for rainwater harvesting tank sizing, i.e., 10 years, as recommended by Mitchell et al. [30].

The mean annual rainfall value for each station was calculated as:

$$
P=365 \cdot\left(\sum_{t=1}^{N} P_{t} / N\right)
$$

where: $P_{t}$ is the daily rainfall depth of the $t$ th day; and $N$ is the total number of recorded rainfall depths.

The longest annual dry period was determined by the maximum period in days without rain or effective rainfall depth less or equal to $1 \mathrm{~mm}$ [5].

\subsection{Daily Water Balance Model}

A daily water balance model was used considering daily rainfall, catchment area, runoff coefficient, tank volume, water needs, and evaporation. The water balance model equation applied for tank sizing is

$$
S_{t}=S_{t-1}+R_{t}-D_{t}-\mathrm{E}_{\mathrm{t}} \quad 0 \leq S_{t-1} \leq V_{\tan k}
$$

where $S_{t}$ is the stored volume at the end of $t$ th day $\left(\mathrm{m}^{3}\right), S_{t-1}$ is the stored volume at the beginning of $t$ th day $\left(\mathrm{m}^{3}\right), R_{t}$ is the harvested rainwater volume during the $t$ th day $\left(\mathrm{m}^{3}\right)$, $D_{t}$ is the daily water demand $\left(\mathrm{m}^{3}\right), E_{t}$ is the daily evaporation in the case of the uncovered tank $\left(\mathrm{m}^{3}\right)$, and $V_{\text {tank }}$ is the capacity of rainwater tank $\left(\mathrm{m}^{3}\right)$.

The daily scale was applied considering the purpose of the study and the data availability [31].

\subsubsection{Harvested Rainwater Volume $\left(R_{t}\right)$}

The daily harvested rainwater volume, $R_{t}\left(\mathrm{~m}^{3}\right)$, from the greenhouse roof area is calculated as

$$
R_{t}=C \cdot A \cdot P_{t},
$$

where $C$ is the runoff coefficient, $A$ is the roof area of the greenhouse used as rainfall collection area $\left(\mathrm{m}^{2}\right)$, and $P_{t}$ is the daily rainfall depth at the end of $t^{\text {th }}$ day $(\mathrm{m})$.

Taking into consideration that the greenhouses examined in this study are made from plastic or glass, a runoff coefficient $C=0.9$ was used [32].

\subsubsection{Water Demand $\left(D_{t}\right)$}

The calculation of daily water demand $\left(D_{t}\right)$ was carried out considering the daily water needs of two different greenhouse crops, a vegetable (tomato) and an ornamental (begonia).

To calculate the water demand of tomato plants $\left(D_{t, \text { tomato }}\right)$, the literature data for tomato crops cultivated in a plastic and unheated greenhouse in Ierapetra (Crete, Greece) for an eight-month growing period (1 October to 31 May) irrigated by drip irrigation method [33,34] were used. For the period from October (planting) to February, due to both low growth stages of crop and low temperatures, there was a slow plant growth and low production, therefore, the water needs were low and ranged from 0.4 to $0.8 \mathrm{~mm}$ day $^{-1}$. Vigorous growth started in March, when the plants had reached the stage of maturity and the optimal climatic conditions for the crop prevail, and was completed in May. During this period, the water needs of the plants ranged from 2 to $3 \mathrm{~mm} \mathrm{day}^{-1}$ [33].

It should also be noted that at the beginning of the cultivation period (1 October) the greenhouse soil was adequately irrigated ensuring the available soil moisture for tomato 
plants. Taking into account that the soil used is characterized as sandy loam-loam [33] with an average available moisture value of $14 \%$ and a rhizosphere depth of $30 \mathrm{~cm}$, an amount of water equal to $42 \mathrm{~mm}\left(42 \mathrm{~m}^{3}\right.$ per $\left.1000 \mathrm{~m}^{2}\right)$ is required to ensure the available soil moisture. Consequently, this amount of water will be applied at the beginning of each new cultivation period ( 1 October) and will be practically required to be covered by the harvested rainwater $\left(I_{r_{-} \text {October }}{ }^{\text {st }}\right)$ through the water balance model.

According to the abovementioned, the daily water demand of the greenhouse tomato plants is calculated from the equation

$$
D_{t, \text { tomato }}=I_{r_{-} \text {October }}{ }^{\text {st }}+C_{c} \cdot A \cdot I_{r, t}
$$

where $C_{c}$ is the coefficient of coverage of the greenhouse area with plants, $A$ is the greenhouse area $\left(\mathrm{m}^{2}\right), I_{r_{-} \text {October1 }}{ }^{\text {st }}$ is the water demand at the beginning (1 October) of each new cultivation period $\left(\mathrm{m}^{3}\right), I_{r, t}$ is the daily water needs of plants $(\mathrm{m})$ for the eight-month growing period (October-May).

The $C_{c}$ coefficient is equal to the percentage of greenhouse area covered by plants. In this study, $C_{c}=0.9$ considering that the tomato plants cover $90 \%$ of the greenhouse area. The remaining $10 \%$ is covered by auxiliary areas and corridors.

On the other hand, to calculate the water demand of the begonia crop $\left(D_{t, \text { begonia }}\right)$, the water needs of begonia plants were obtained from a previous study of begonia cultivation in a glass and heated greenhouse in the Agricultural University of Athens (Attica, Greece) [35]. Taking into consideration that begonia is cultivated all year round in Greek greenhouses, this means that plants of different growth stages will coexist in the greenhouse. Thus, we assume four different growth stages and the daily water needs of plants, $I_{r \text {,stage_i }}$ are given as:

- $\quad$ 1st growth stage: $I_{r, \text { stage_1 }}=0.5 \mathrm{mmd}^{-1}$;

- 2nd growth stage: $I_{r, \text { stage_2 }}=1.5 \mathrm{mmd}^{-1}$;

- $\quad 3$ rd growth stage: $I_{r, \text { stage_3 }}=2.1 \mathrm{mmd}^{-1}$;

- $\quad$ 4th growth stage: $I_{r, \text { stage_4 }}=2.7 \mathrm{mmd}^{-1}$.

Consequently, the daily water demand of the greenhouse begonia plants is calculated from the equation

$$
D_{t, \text { begonia }}=\frac{1}{4} \cdot C_{c} \cdot A \cdot\left(I_{r, \text { stage } \_1}+I_{r, \text { stage_2 } 2}+I_{r, \text { stage_3 } 3}+I_{r, \text { stage } \_4}\right),
$$

Similar to the case of tomato cultivation, the $C_{c}$ coefficient is equal to 0.9 .

\subsubsection{Evaporation Losses from Uncovered Rainwater Harvesting Tank $\left(E_{t}\right)$}

The case of uncovered rainwater harvesting tanks that are used to meet the water needs of greenhouse tomato crops grown in Crete, was also investigated. Daily evaporation values used were calculated from mean monthly values. Available monthly evaporation data from "Tympaki" station [36], representative of the study area, are presented in Table 1.

\begin{tabular}{|c|c|c|c|c|c|c|c|c|c|c|c|c|c|}
\hline Month & Jan & Feb & Mar & Apr & May & Jun & Jul & Aug & Sept & Oct & Nov & Dec & Total \\
\hline Evaporation depth (mm) & 82.6 & 83.9 & 119.1 & 147.4 & 210.1 & 270.5 & 358.8 & 333.5 & 228.1 & 163.5 & 102.4 & 87.3 & 2187.2 \\
\hline
\end{tabular}

Table 1. Mean monthly evaporation data used.

Daily evaporation values, $E_{t}$, were obtained as:

$$
E_{t}=\frac{E_{i}}{n_{i}}
$$

where $E_{i}$ is the evaporation depth of the $i$ th month $(\mathrm{m}) ; n_{i}$ is the number of days of the ith month. 
For begonia greenhouse crops in Attica, evaporation losses from uncovered tanks were not calculated since neither these tanks are used in this case, nor relative data were available.

\subsection{Rainwater Tank Sizing}

Taking into account the harvested rainwater and the water demand for each crop studied, the water balance model equations used are given by Equation (7) for the tomato crop and uncovered rainwater tanks, Equation (8) for the tomato crop and covered rainwater tanks, and Equation (9) for the begonia crop and covered rainwater tanks:

$$
\begin{gathered}
S_{t}=S_{t-1}+C \cdot A \cdot P_{t}-I_{r_{-} \text {October } 1{ }^{\text {st }}}-C_{c} \cdot A \cdot I_{r, t}-E_{t}, \\
S_{t}=S_{t-1}+C \cdot A \cdot P_{t}-I_{r_{-} \text {October } 1 \text { st }}-C_{c} \cdot A \cdot I_{r, t}, \\
S_{t}=S_{t-1}+C \cdot A \cdot P_{t}-\frac{1}{4} \cdot C_{c} \cdot A \cdot\left(I_{r, t_{-} \text {stage } 1}+I_{r, t_{\text {_stage }}}+I_{r, t_{-} \text {stage } 3}+I_{r, t_{-} \text {tstage }}\right),
\end{gathered}
$$

The calculation of daily stored rainwater volume is iterative and starts from an initial stored water volume $S_{t-1}=S_{0}$ at time $t=0$. The most conservative value of $S_{0}$ is $S_{0}=0$ for an initially empty rainwater tank, and the less conservative is the maximum value $S_{0}=V_{\text {tank }}$ for an initially full rainwater tank. Any other value $S_{0}$ for a partially full rainwater tank can also be used [20].

The following heuristic algorithm was used iteratively for calculating the daily stored rainwater in the tank considering the capacity of the tank, $V_{\text {tank }}$ :

$$
\text { if } S_{t} \succ V_{\text {tank }} \text { then } V_{\text {tank }} \text {, if } S_{t} \prec 0 \text { then } 0 \text { else } S_{t}=S_{t, \text { tank }} \text {, }
$$

where $S_{t, \operatorname{tank}}$ is the actual available stored water volume in the tank at the $t$ th day as given by Equations (7)-(9).

When the tank is full, the water volume which overflows, $O_{t}$, from the tank can be computed from the following algorithm:

$$
\text { if } S_{t} \geq V_{\text {tank }} \text { then } O_{t}=S_{t}-V_{\text {tank }} \text { else } O_{t}=0 \text {, }
$$

Overflow happens only after the water demand has been met.

When the stored rainwater volume in the tank, $S_{t, \text { tank }}$, is inadequate to meet the demand, $D_{t}$, then the demand will be met by water, $T_{t}$, from other sources, e.g., public network or private drills, which can be calculated as follows:

$$
\text { if } S_{t, \text { tank }} \prec D_{t} \text { then } T_{t}=D_{t}-S_{t, \text { tank }} \text { else } T_{t}=0 \text {, }
$$

In the present study, a full rainwater tank was assumed initially, and the values of rainwater collection areas studied were 1000, 3000,5000, 6000, and 10,000 $\mathrm{m}^{2}$, because such greenhouse cultivated areas are commonly used in the study areas. Moreover, no license is required to construct rainwater tanks of $500 \mathrm{~m}^{3}$ per $3000 \mathrm{~m}^{2}$ greenhouse cultivated area in Crete, according to the Ministerial Decision 5656/18-09-2015 [12].

\subsection{Reliability Analysis of Rainwater Harvesting System}

The reliability coefficient, $R e$, was used to estimate the efficiency of a RWH tank for a demand level [21]. The coefficient $R e$ expresses the ability of the rainwater tank to satisfy the water needs of tomato and begonia crops and is given by the following equation:

$$
R e=\frac{N_{f}}{N_{t o t}} \cdot 100(\%),
$$

where $N_{f}$ is the number of days where the intended demand is fully met by the available stored rainwater and $N_{\text {tot }}$ is the total number of days simulated. 
In this study, the reliability coefficient was calculated using daily rainfall data records on a continuous time series for a simulation period of 12 years $\left(N_{t o t}=4383\right.$ days).

\section{Results and Discussion}

From the analysis of the daily rainfall data for the two stations used, the mean annual rainfall values $(P)$, as well as the maximum $\left(N_{d d, \max }\right)$, minimum $\left(N_{d d, \text { min }}\right)$, and mean $\left(N_{d d}\right)$ values of the longest annual dry periods are given in Table 2 . Both stations are characterized by similar low annual rainfall values but by different dry periods ranged approximately from 2.5 to 4 consecutive months. Specifically, the "Athens" and "Ierapetra" stations have mean annual rainfall 447.87 and $418.93 \mathrm{~mm}$ and mean longest annual dry period 71.83 and 123.92 days, respectively.

Table 2. Rainfall station characteristics, mean annual rainfall values $(P)$, mean, max. and min. values of the longest annual dry periods $\left(N_{d d}, N_{d d, \text { max }}, N_{d d, \text { min }}\right)$ of the 12-years rainfall time series (2008-2020) of the studied stations.

\begin{tabular}{ccccccccc}
\hline $\begin{array}{c}\text { Rainfall } \\
\text { Station }\end{array}$ & $\begin{array}{c}\text { Administrative } \\
\text { Region }\end{array}$ & $\begin{array}{c}\text { Altitude } \\
(\mathbf{m})\end{array}$ & $\begin{array}{c}\text { Longitude } \\
\text { (Deg.) }\end{array}$ & $\begin{array}{c}\text { Latitude } \\
\text { (Deg) }\end{array}$ & $\boldsymbol{P}$ (mm) & $\begin{array}{c}\boldsymbol{N}_{d d} \\
\text { (Days) }\end{array}$ & $\begin{array}{c}N_{d d, m a x} \\
\text { (Days) }\end{array}$ & $\begin{array}{c}N_{d d, m i n} \\
\text { (Days) }\end{array}$ \\
\hline Athens & Attica & 50 & 23.71545 & 37.97841 & 447.87 & 71.83 & 109 & 30 \\
Ierapetra & Crete & 5 & 25.74899 & 35.01019 & 418.93 & 123.92 & 173 & 92 \\
\hline
\end{tabular}

The distribution of daily rainfall depths during the 12 years time period used is presented in Figure 3. In both stations, the rainfall is concentrated in the winter wet period (October to April) of each year, with low daily values (mainly $<25 \mathrm{~mm}$ ), leaving a distinctive summer dry period (May to September), typical of the Mediterranean climate type.

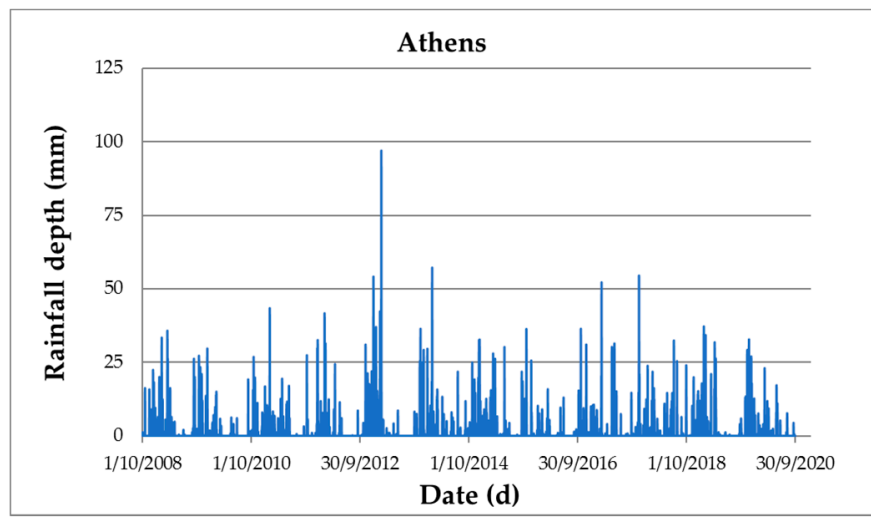

(a)

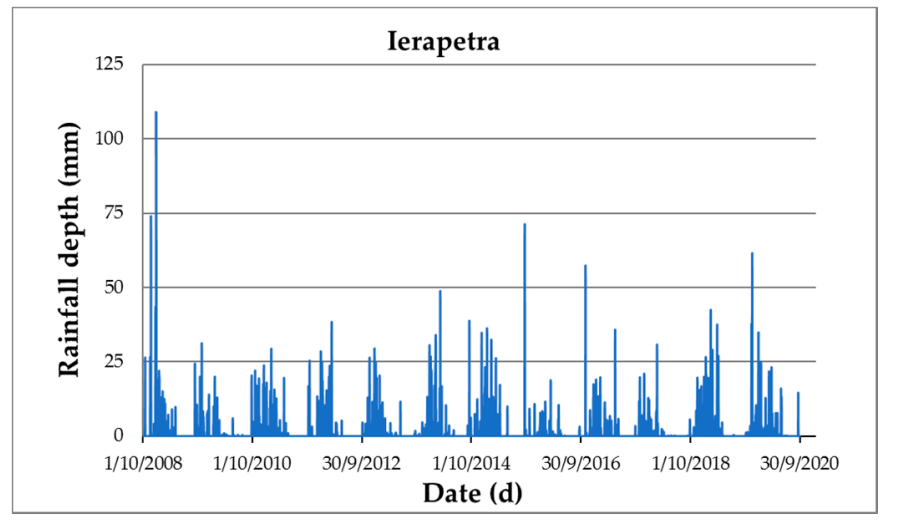

(b)

Figure 3. Distribution of daily rainfall depth for the period 2008-2020 at the station: (a) Athens (Attica, Greece); (b) Ierapetra (Crete, Greece).

In the following figure (Figure 4), the reliability curves in relation to the rainwater harvesting tank sizes for covered tanks to meet the water needs of a begonia crop for different greenhouse areas are depicted. Specifically, as shown in Figure 4a, a reliability coefficient of $65 \%$ was calculated for a covered tank of $100 \mathrm{~m}^{3}$ volume and water collection area of $1000 \mathrm{~m}^{2}$ which are commonly used for greenhouse ornamental crops in the Attica region. The duplication of tank volume $\left(200 \mathrm{~m}^{3}\right)$ led to only a $7 \%$ increase of the $R e$. However, the suitable tank volume to fully meet the water needs of plants $(\operatorname{Re}=100 \%)$ is disproportionately large (approx. $1900 \mathrm{~m}^{3}$ ). Similar results are presented in the case of the other collection areas examined (Figure $4 \mathrm{~b}-\mathrm{e}$ ). The comparison between $R e$ and $V_{\text {tank }}$ for all collection areas showed that a tank volume of $100 \mathrm{~m}^{3}$ per $1000 \mathrm{~m}^{2}$ collection area is required to achieve a reliability of $65 \%$, while a Re value of $72 \%$ is reached with $200 \mathrm{~m}^{3}$ tank volume per $1000 \mathrm{~m}^{2}$ collection area (Figure $4 \mathrm{f}$ ). 


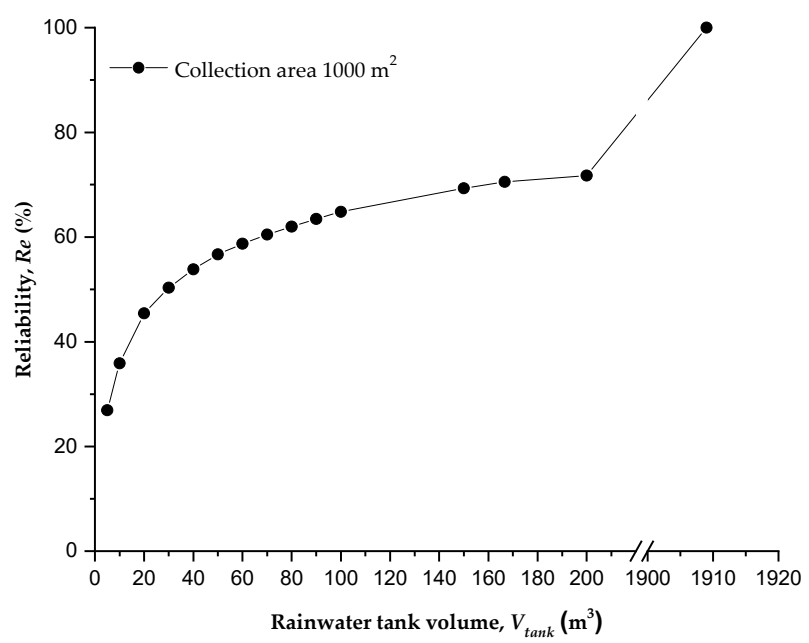

(a)

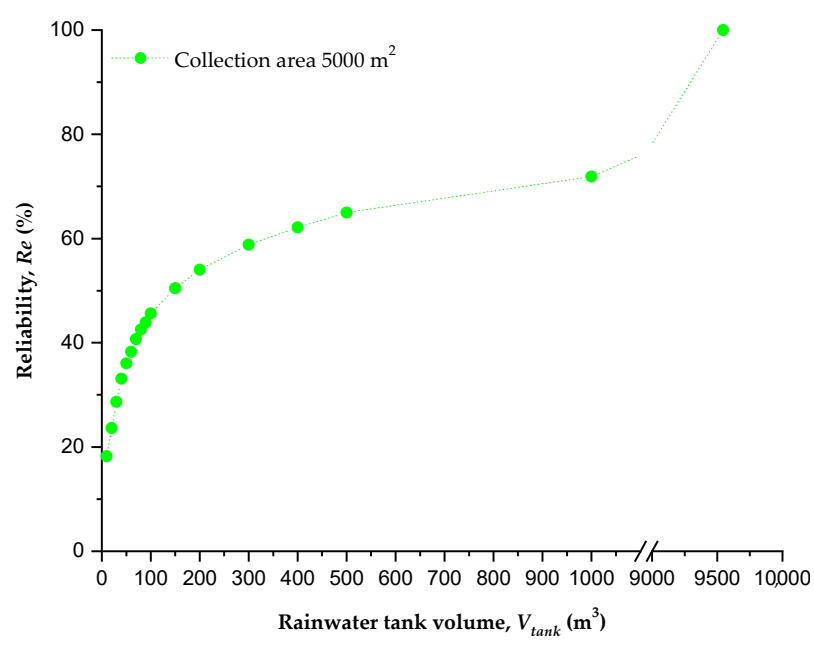

(c)

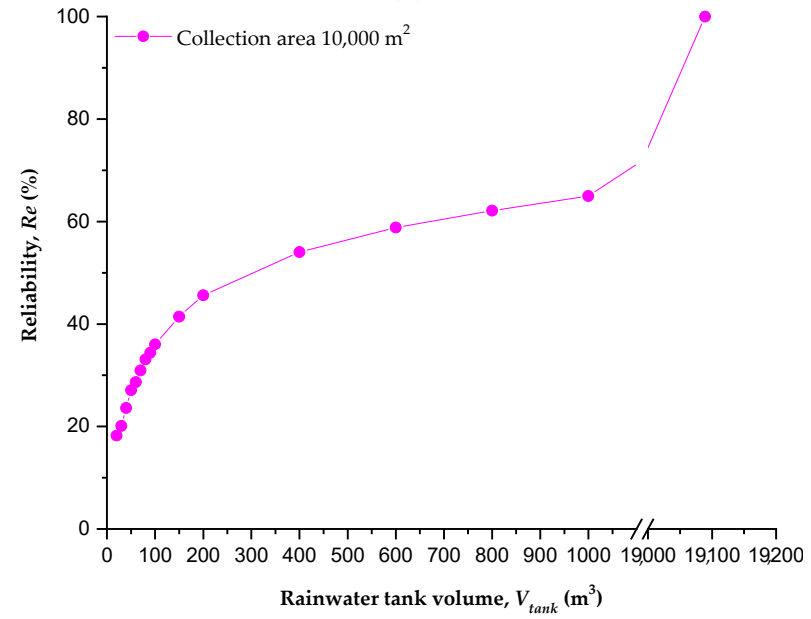

(e)

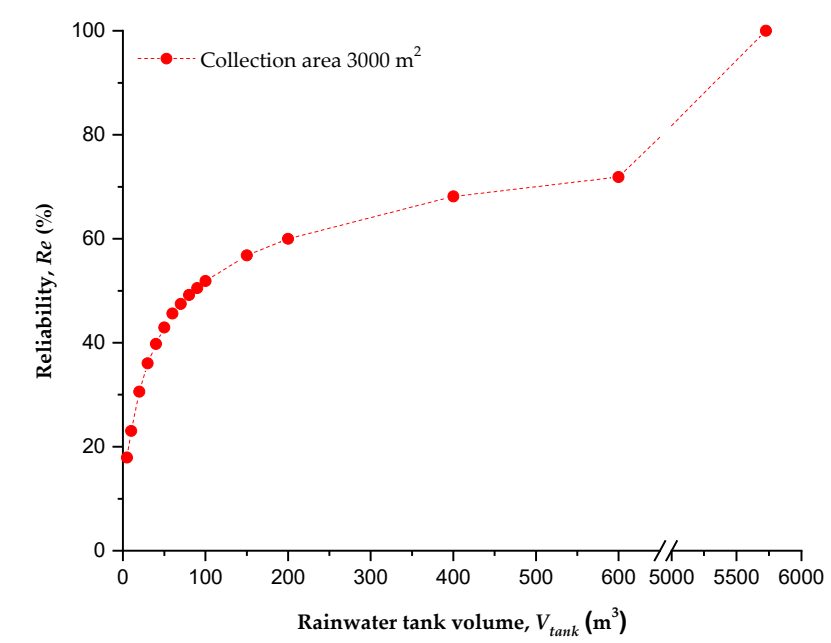

(b)

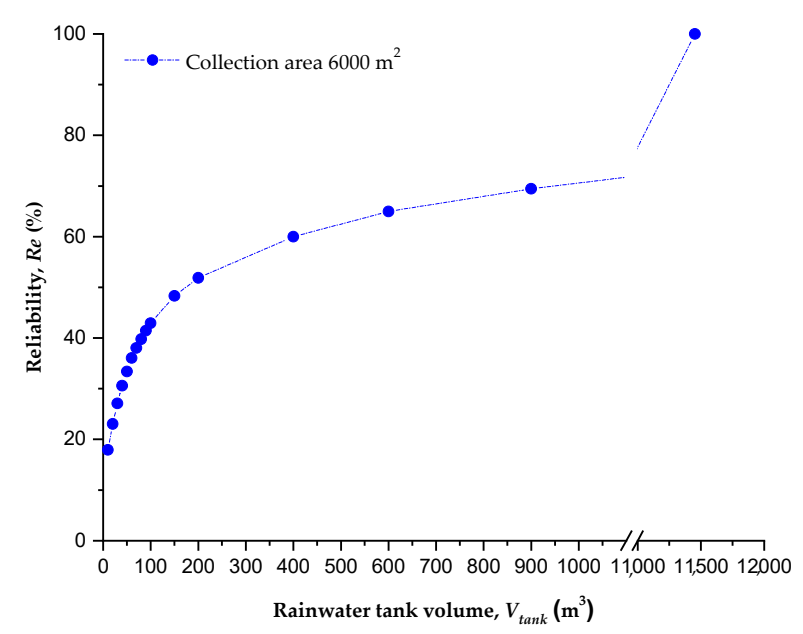

(d)

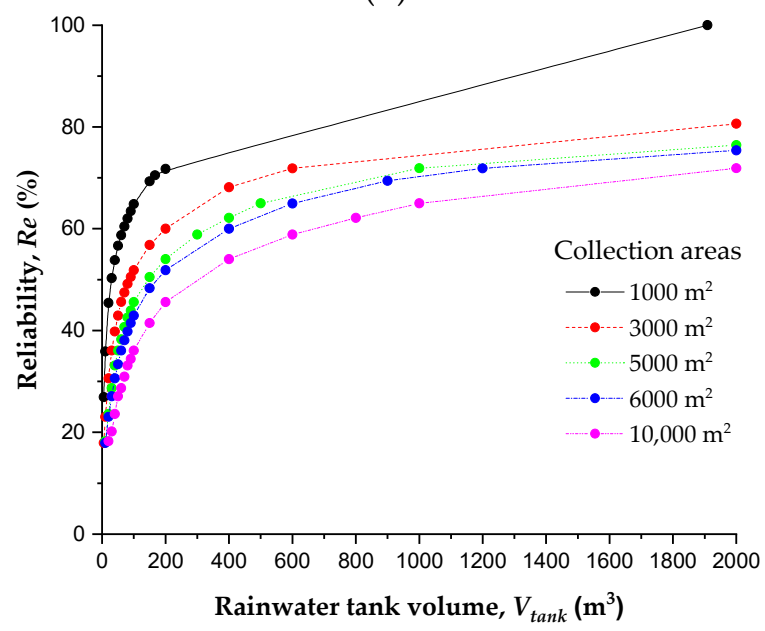

(f)

Figure 4. Reliability curves of covered rainwater harvesting system in relation to tank sizes to meet the demand of begonia crop cultivated in greenhouses with rainwater collection areas: (a) $1000 \mathrm{~m}^{2}$; (b) $3000 \mathrm{~m}^{2}$; (c) $5000 \mathrm{~m}^{2}$; (d) $6000 \mathrm{~m}^{2}$; and (e) 10,000 $\mathrm{m}^{2}$. A comparative presentation was also presented for a range of tank sizes from 5 to $2000 \mathrm{~m}^{3}$ (f).

The results obtained from the heuristic algorithm during the rainwater tank sizing procedure, in the case where tank size was $V_{\text {tank }}=100 \mathrm{~m}^{3}$ and initial full of water and 
collection area $A=1000 \mathrm{~m}^{2}$, are presented in Figure 5. As shown in Figure 5a, during the 12 years time period studied, there were several time periods when the tank dried up. For these time periods, the water demand was met by water, $T_{t}$, from other sources (e.g., public network or private drills) with volumes that are given in Figure $5 \mathrm{~b}$. As shown, the required cumulative volume of water was $2258 \mathrm{~m}^{3}$ for the whole period studied. Note that the number is to be expected, as the reliability coefficient for this case is only $65 \%$. The volume of $\mathrm{T}_{t}$ becomes $1807 \mathrm{~m}^{3}$ for $V_{\text {tank }}=200 \mathrm{~m}^{3}(R e=72 \%)$ and $0 \mathrm{~m}^{3}$ for $V_{\text {tank }}=1900 \mathrm{~m}^{3}(R e=100 \%)$. In addition, the overflow water volumes from the tank are presented in Figure $5 \mathrm{c}$. The maximum overflow was $83.43 \mathrm{~m}^{3}$ and the cumulative one for the whole period was $488.85 \mathrm{~m}^{3}$.
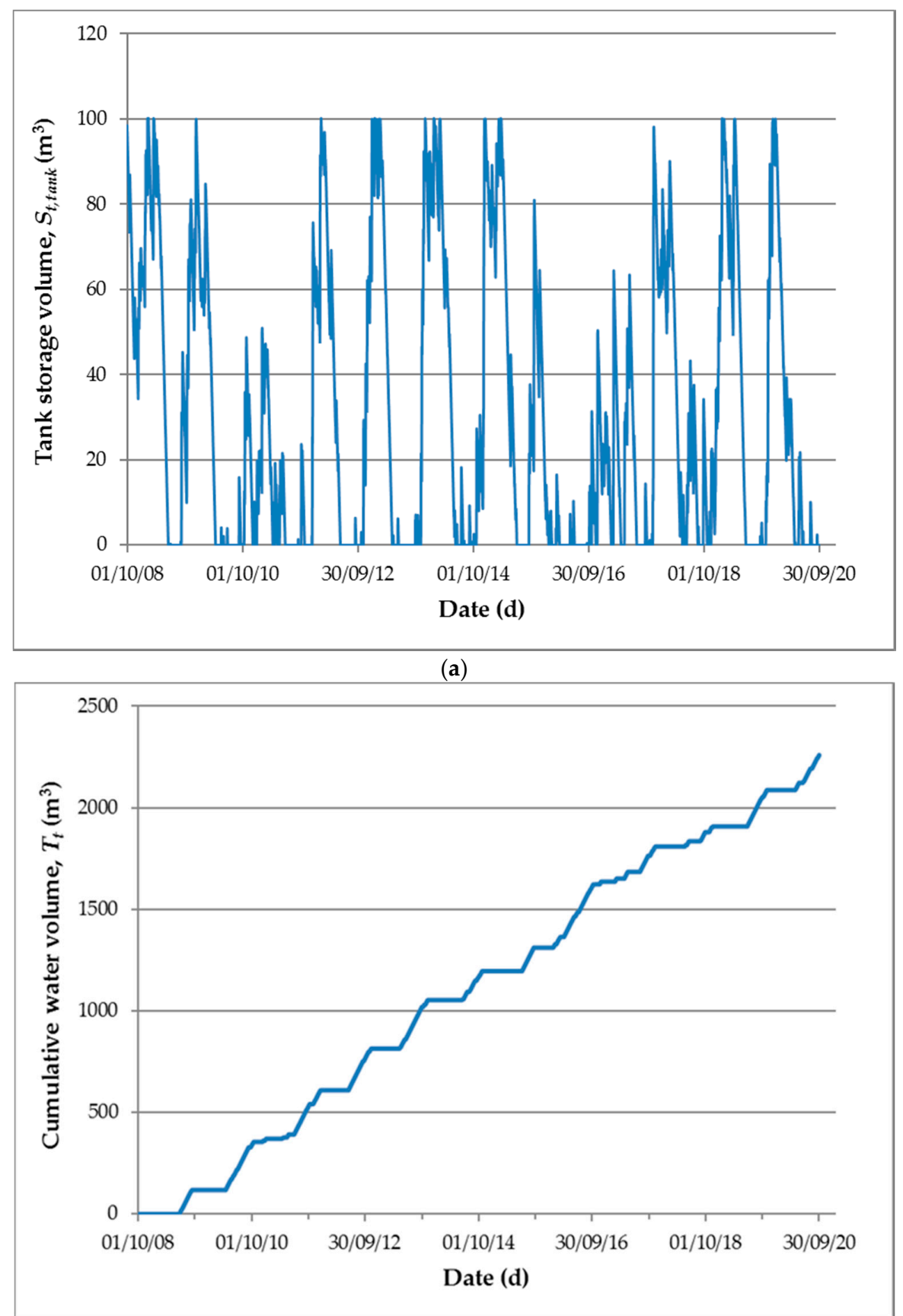

(b)

Figure 5. Cont. 


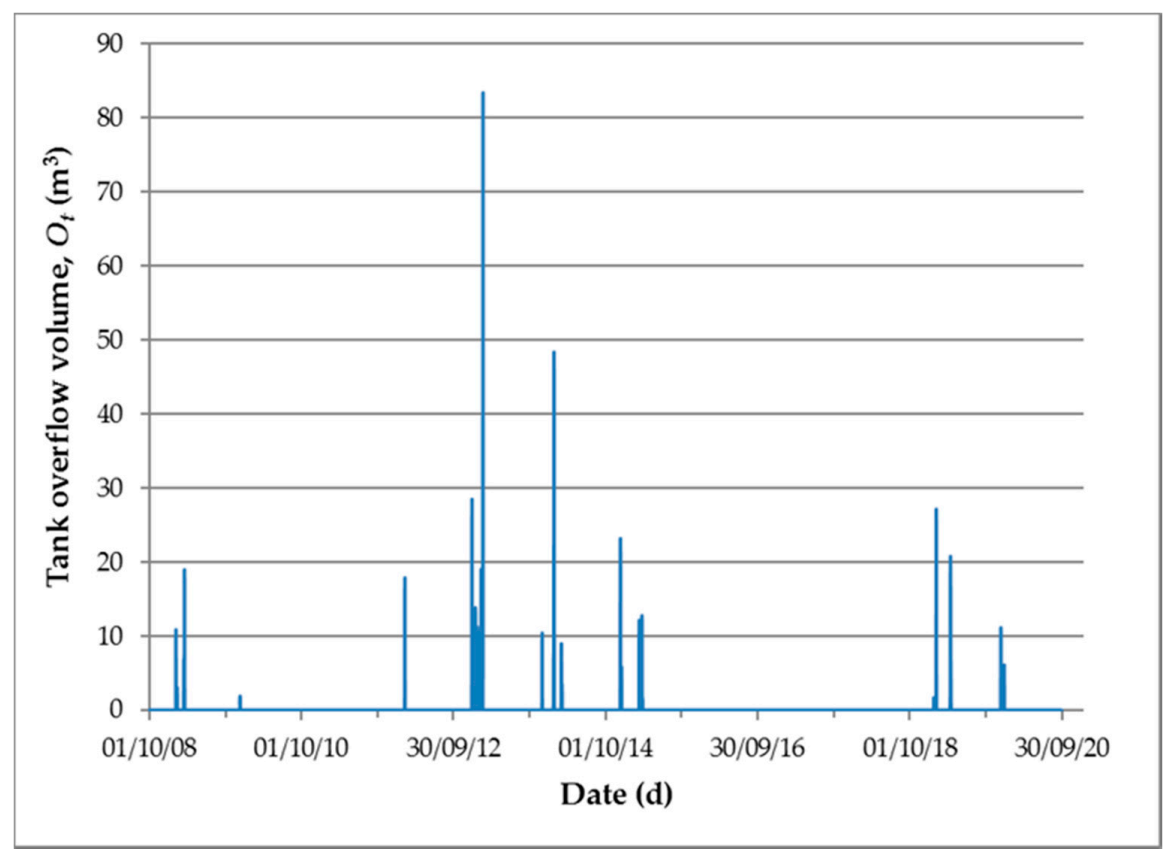

(c)

Figure 5. Stored water volume in the tank (a); cumulative water volume supplied from other sources to meet the water needs of begonia crop (b); and overflow water volume from the tank (c) as computed by applying the daily water balance method for tank size $V_{\text {tank }}=100 \mathrm{~m}^{3}$ and collection area $\mathrm{A}=1000 \mathrm{~m}^{2}$.

In the case of the greenhouse vegetable crop, i.e., tomato, for covered tanks, $R e$ values were greater than $80 \%$ for all tank volumes and collection areas studied (Figure 6). As shown in Figure 6a, for the minimum required tank volume used $\left(42 \mathrm{~m}^{3}\right.$ per $1000 \mathrm{~m}^{2}$ collection area), Re achieved a high value of $82 \%$. Note that the value of $42 \mathrm{~m}^{3}$ per $1000 \mathrm{~m}^{2}$ collection area is the required water volume applied before planting. As the $V_{\text {tank }}$ increases, the $R e$ increases, reaching the value of $100 \%$ for a tank volume of $290 \mathrm{~m}^{3}$. Similar results of high $R e$ values were obtained for all studied collection areas (Figure 6b-e). It is worth noting that according to Greek legislation on RWH tank construction for greenhouse crop irrigation in Crete, for the proposed tank volume of $500 \mathrm{~m}^{3}$ per $3000 \mathrm{~m}^{2}$ collection area, the $R e$ reached the value of $96 \%$ (Figure 6b). From the comparison between $R e$ and $V_{\text {tank }}$ for all collection areas examined (Figure 6f), it can be said that a covered tank of $167 \mathrm{~m}^{3}$ per $1000 \mathrm{~m}^{2}$ greenhouse area can meet $96 \%$ of the water needs of tomato crop cultivated in a greenhouse.

On the other hand, reliability analysis of uncovered tanks to meet the water needs of a tomato crop was performed taken into account the daily evaporation losses from the water surface of uncovered tanks in the daily water balance model. As shown in Figure 7a, the reliability coefficient ranges from $81 \%$ for the minimum required tank volume $\left(42 \mathrm{~m}^{3}\right)$ to $91 \%$ for $177 \mathrm{~m}^{3}$ tank in the case of $1000 \mathrm{~m}^{2}$ collection area. Any further increase in the tank volume led to a decrease in the reliability value. This occurs because the stored rainwater is unable to meet the water demand due to the greater evaporation losses from the increased water surface of uncovered tanks. Similar results are observed in the cases of all collection areas used, as shown in Figure $7 \mathrm{~b}-\mathrm{e}$. In conclusion, the maximum volume of a tank which can be used to meet the water demand is $177 \mathrm{~m}^{3}$ per $1000 \mathrm{~m}^{2}$ collection area, reaching a reliability coefficient of $91 \%$ (Figure $7 \mathrm{f}$ ).

Finally, in Figure 8a comparative presentation between covered and uncovered rainwater tanks for each collection area used is given. As it is anticipated, the best management of stored rainwater is achieved by covered tanks. The reliability of these tanks is always greater than uncovered ones and can reach the value of $100 \%$ with the selection of the appropriate 
tank size. Nevertheless, the reliability of uncovered tanks can reach the maximum value of $91 \%$ for a critical tank volume of $177 \mathrm{~m}^{3}$ per $1000 \mathrm{~m}^{2}$ collection area. For any other tank volume greater than the critical one, the reliability value of the RWH system decreases.

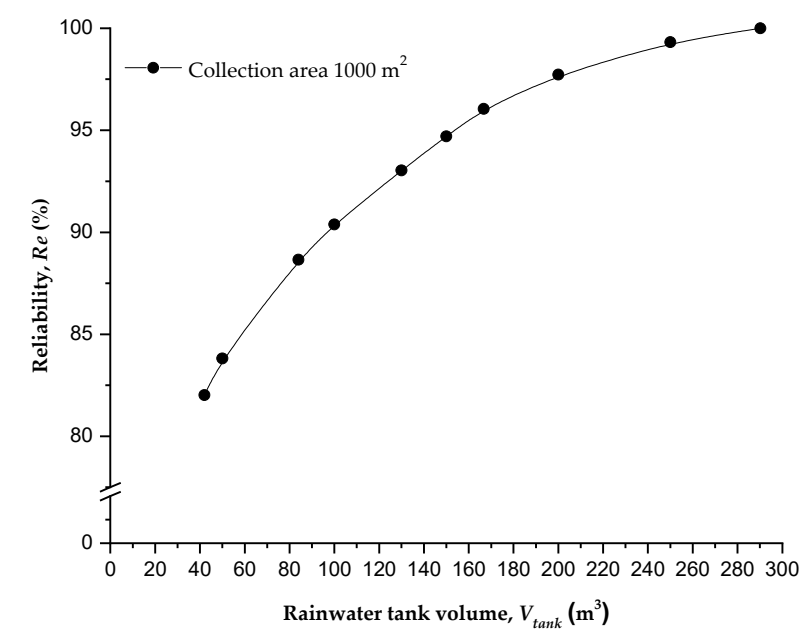

(a)

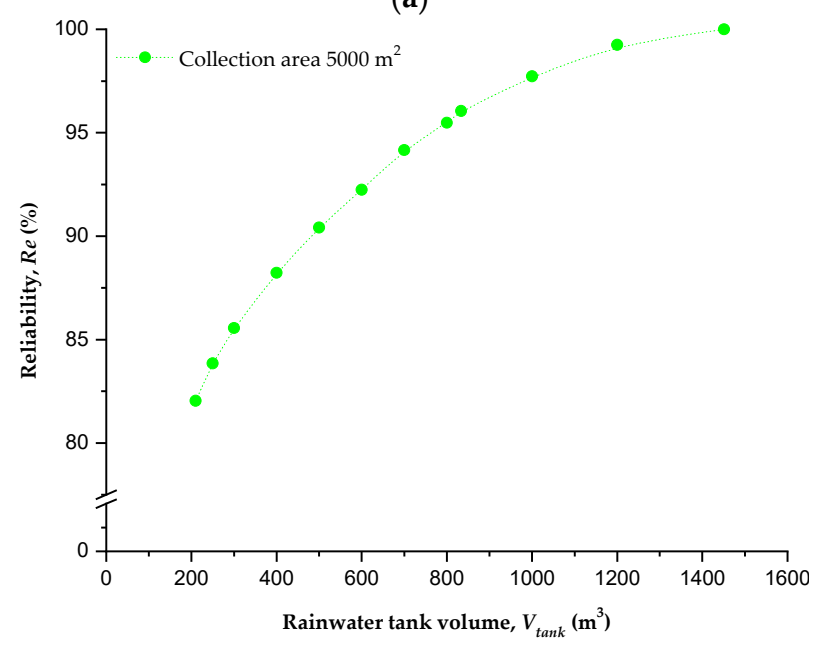

(c)

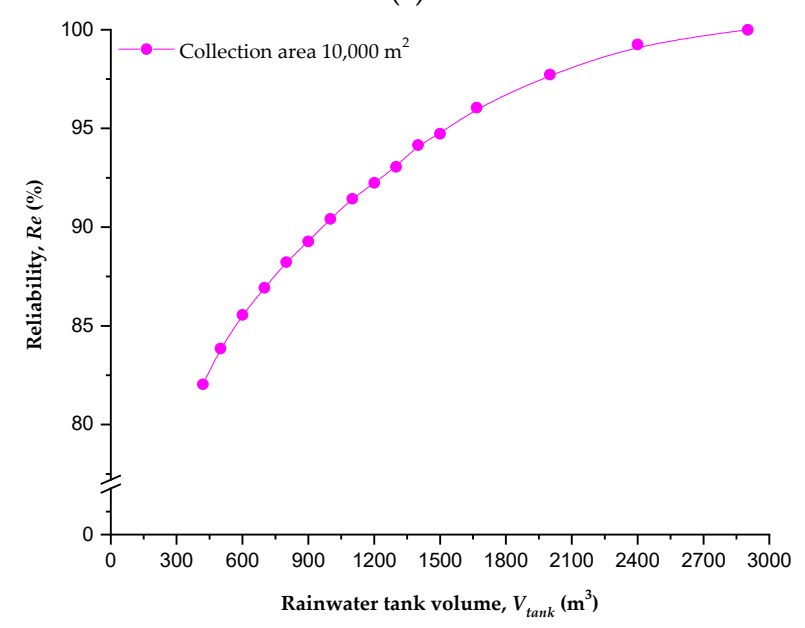

(e)

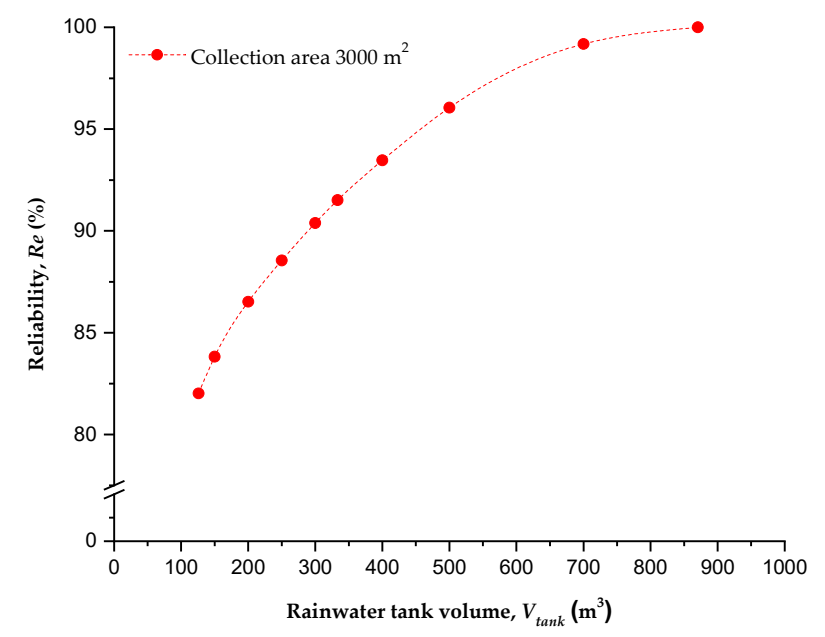

(b)

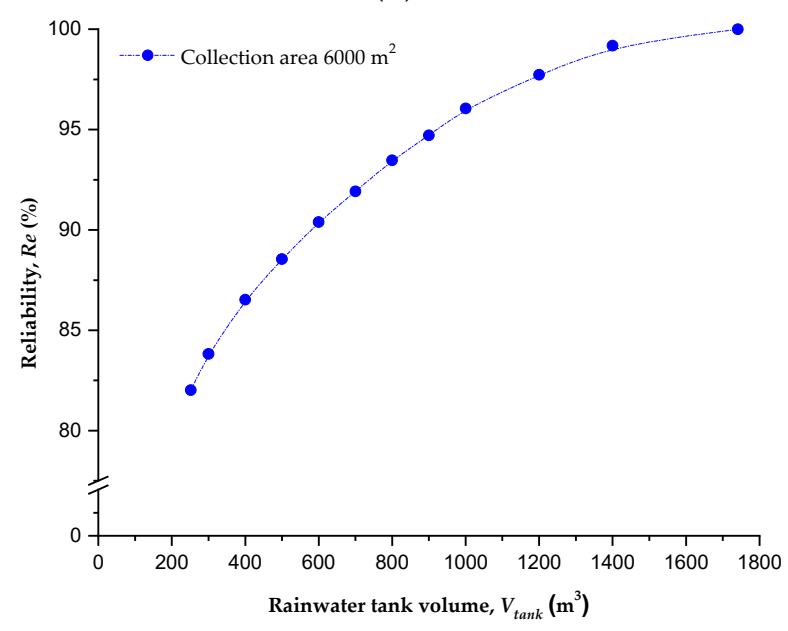

(d)

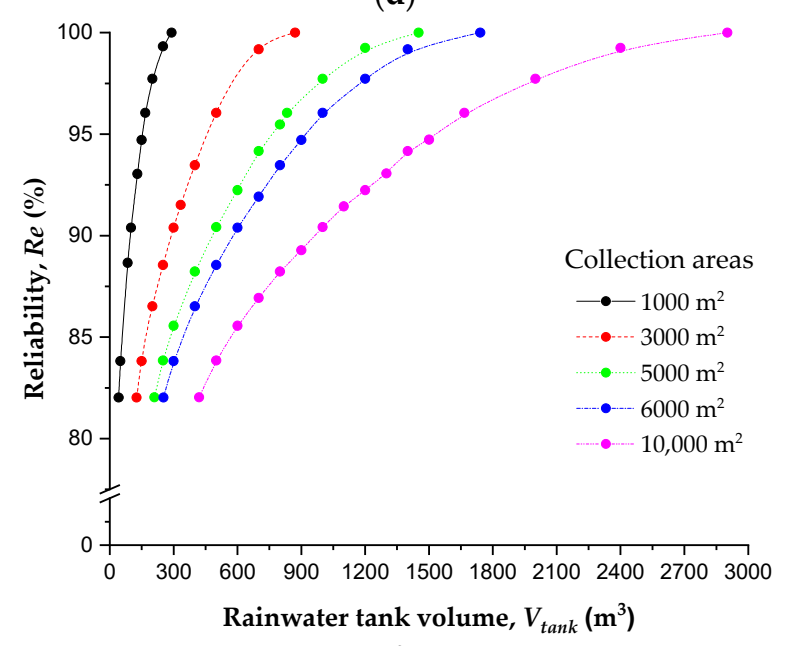

(f)

Figure 6. Reliability curves of covered rainwater harvesting system in relation to tank sizes to meet the demand of a tomato crop cultivated in greenhouses with rainwater collection areas: (a) $1000 \mathrm{~m}^{2}$; (b) $3000 \mathrm{~m}^{2}$; (c) $5000 \mathrm{~m}^{2}$; (d) $6000 \mathrm{~m}^{2}$; and (e) $10,000 \mathrm{~m}^{2}$. A comparative presentation was also presented (f). 


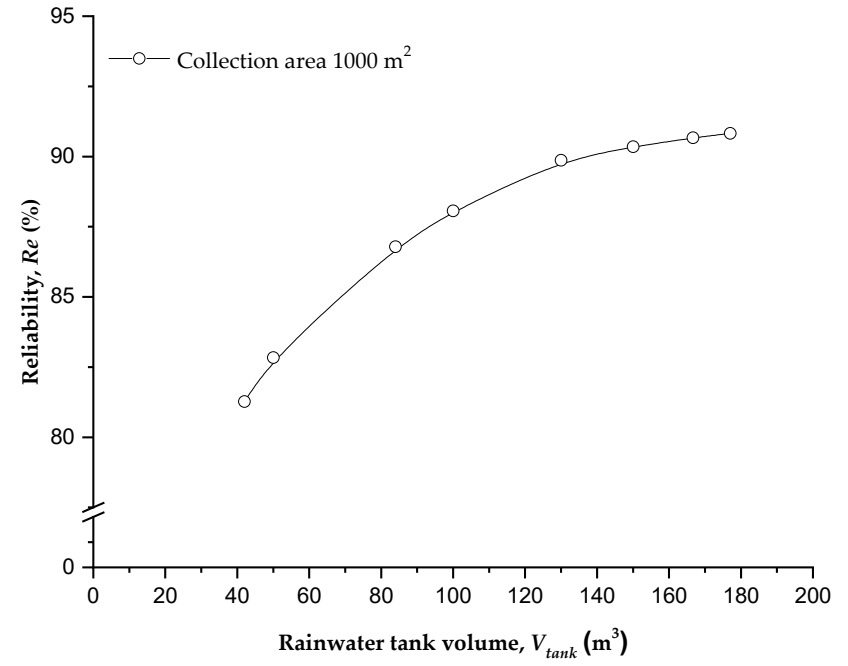

(a)

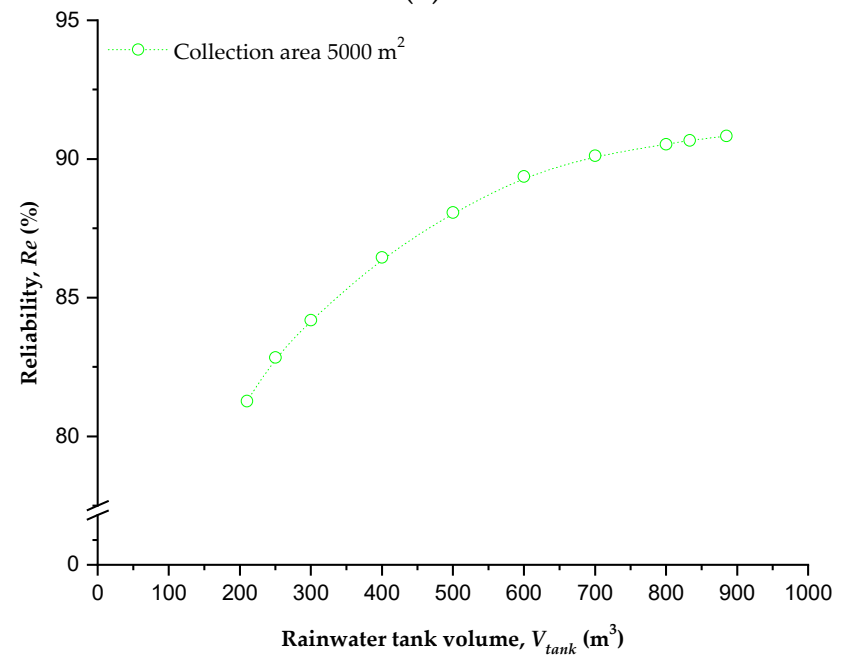

(c)

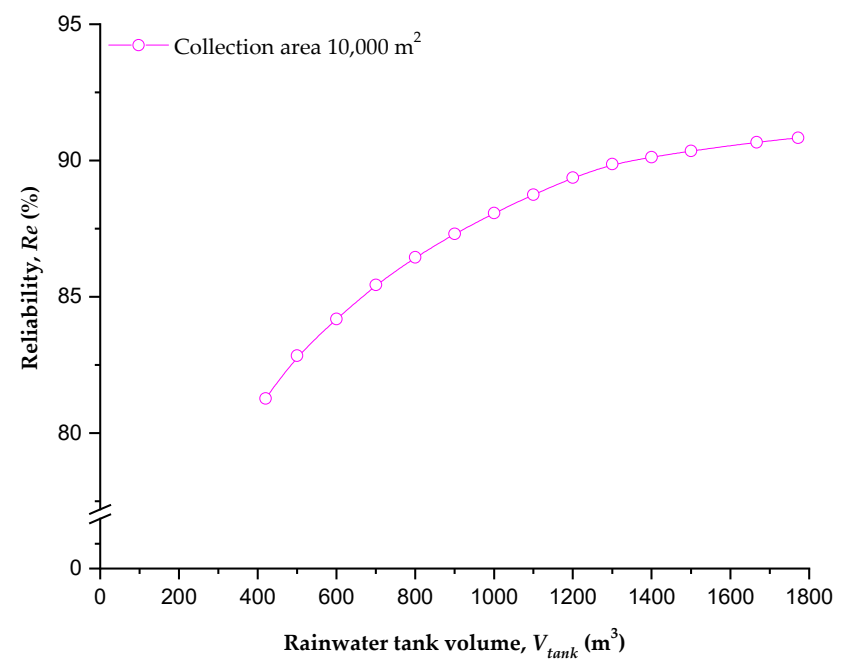

(e)

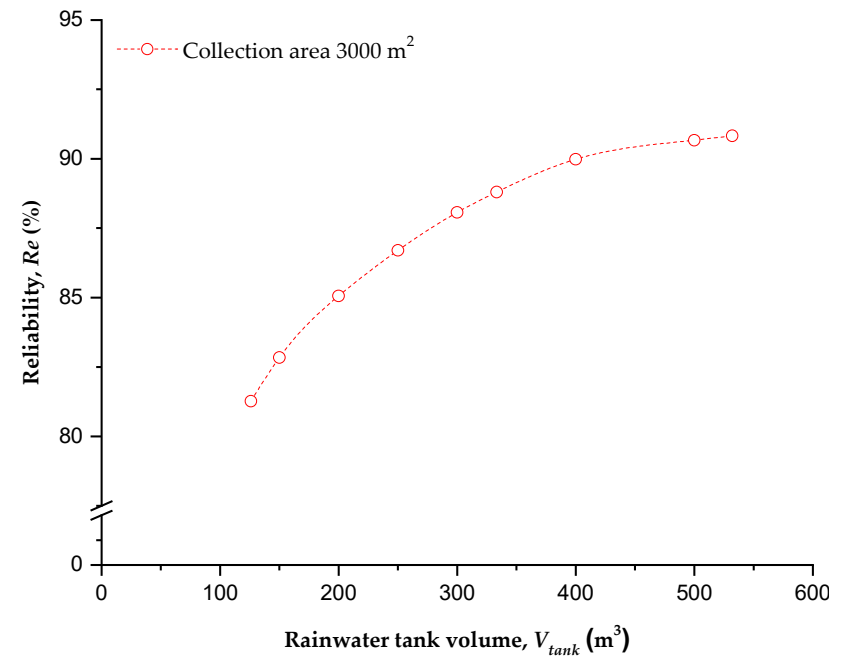

(b)

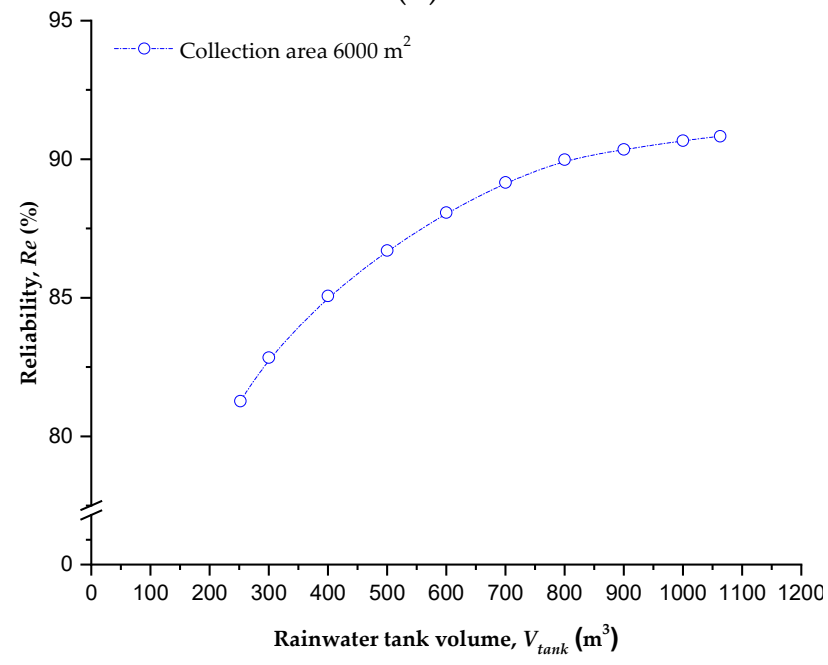

(d)

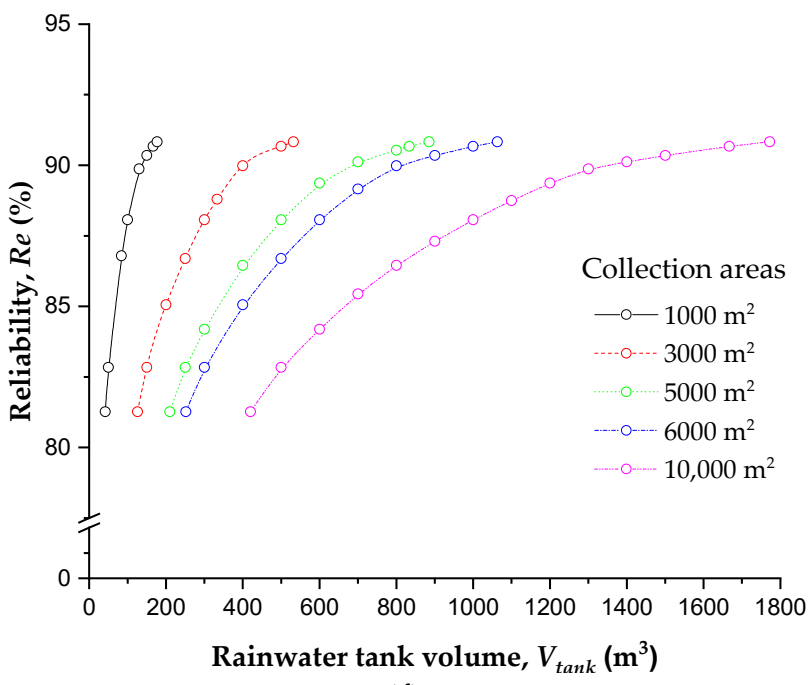

(f)

Figure 7. Reliability curves of covered rainwater harvesting system in relation to tank sizes to meet the demand of a tomato crop cultivated in greenhouses with rainwater collection areas: (a) $1000 \mathrm{~m}^{2}$; (b) $3000 \mathrm{~m}^{2}$; (c) $5000 \mathrm{~m}^{2}$; (d) $6000 \mathrm{~m}^{2}$; and (e) $10,000 \mathrm{~m}^{2}$. A comparative presentation was also presented (f). 


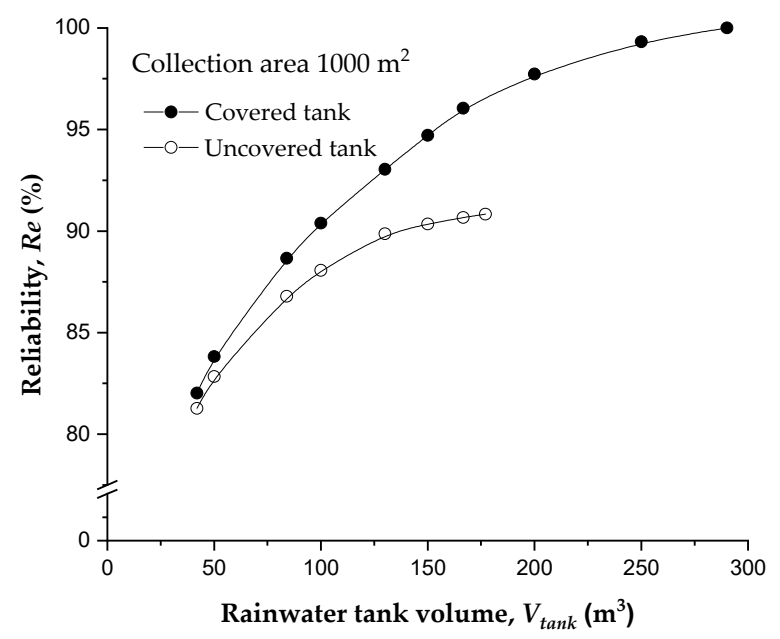

(a)

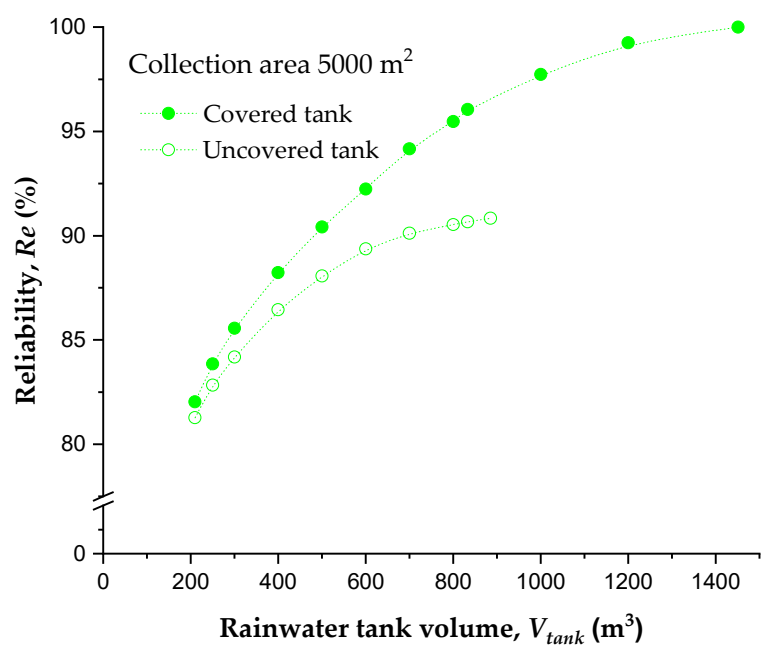

(c)

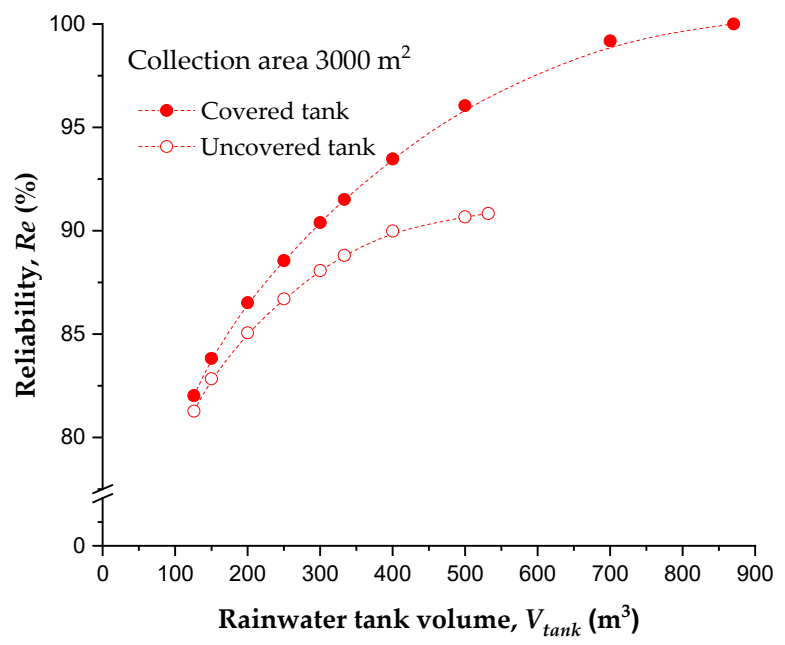

(b)

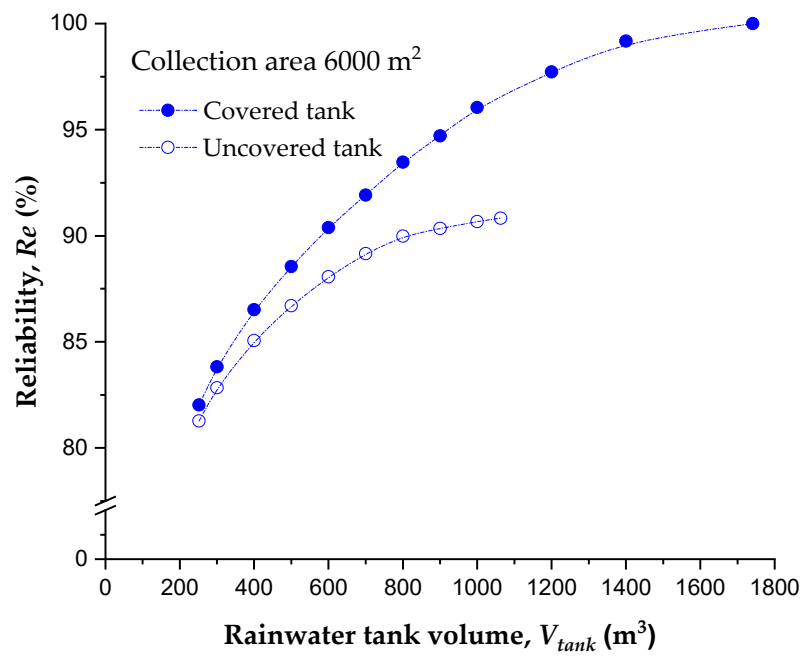

(d)

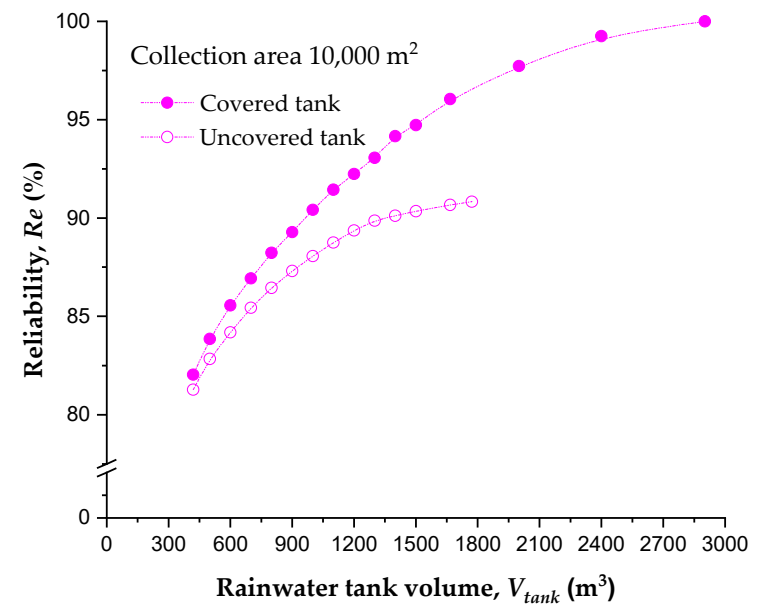

(e)

Figure 8. Comparative presentation of reliability curves in relation to tank sizes between covered and uncovered rainwater harvesting system to meet the demand of a tomato crop cultivated in greenhouses with rainwater collection areas: (a) $1000 \mathrm{~m}^{2}$; (b) $3000 \mathrm{~m}^{2}$; (c) $5000 \mathrm{~m}^{2}$; (d) $6000 \mathrm{~m}^{2}$; and (e) $10,000 \mathrm{~m}^{2}$.

In Figure 9, the results obtained from the heuristic algorithm during the covered and uncovered rainwater tank sizing procedure, in the case where tank size was $V_{\text {tank }}=167 \mathrm{~m}^{3}$ 
and initial full of water and collection area $A=1000 \mathrm{~m}^{2}$, are presented. As shown in Figure $9 a, b$, during the whole time period studied, the time periods where the uncovered tank has dried up are much longer than those of the covered tank. This is due to the higher demand in the case of the uncovered tank because of the evaporation from the water surface. As it is anticipated, for these time periods, the water volume from other sources, $T_{t}$, to meet the water demand from the uncovered tank is three times greater than this of the covered tank. Specifically, the required cumulative volume of water is $287.64 \mathrm{~m}^{3}$ and $851.81 \mathrm{~m}^{3}$ for the covered and uncovered tank, respectively, for the whole period studied (Figure $9 \mathrm{c}, \mathrm{d}$ ). It is worth noting that the corresponding reliability coefficients are $96 \%$ for the covered and $90.7 \%$ for the uncovered tank. Finally, both covered and uncovered tanks have a similar distribution of overflow volume during the 12 years time period with lower volumes in the case of an uncovered tank (Figure 9e,f). The maximum overflows are 97.45 and $96.82 \mathrm{~m}^{3}$, and the cumulative ones are 1252.75 and $1014.52 \mathrm{~m}^{3}$ for covered and uncovered tanks, respectively, for the whole period studied.

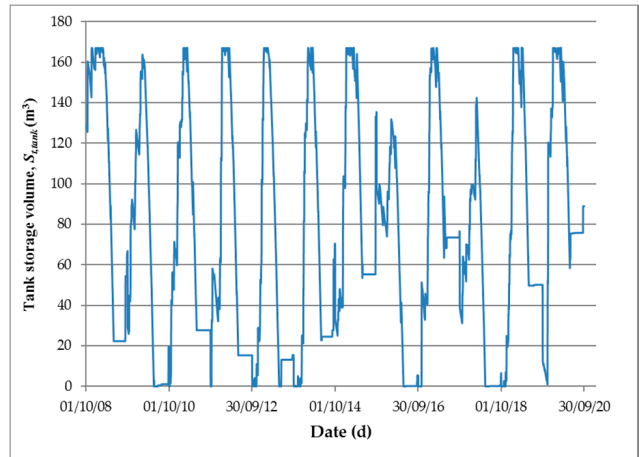

(a)

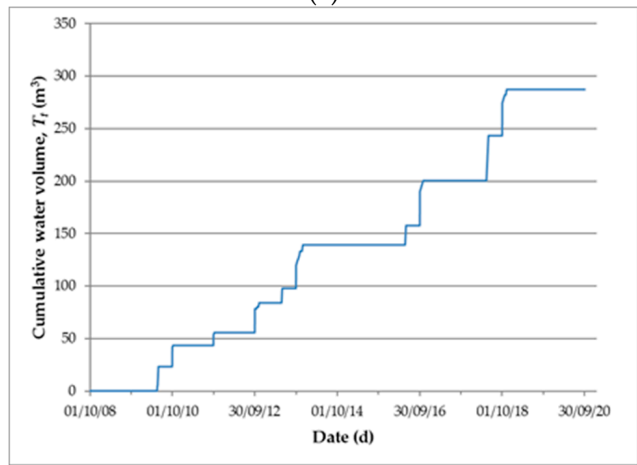

(c)

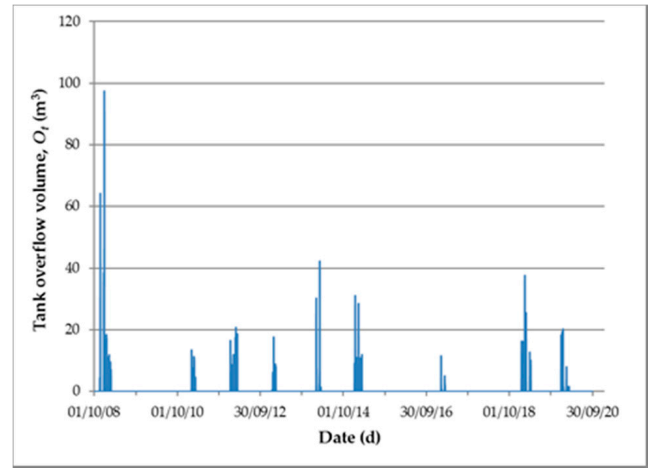

(e)

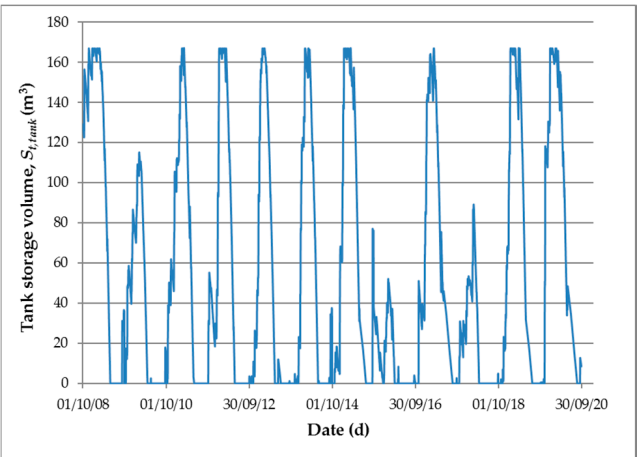

(b)

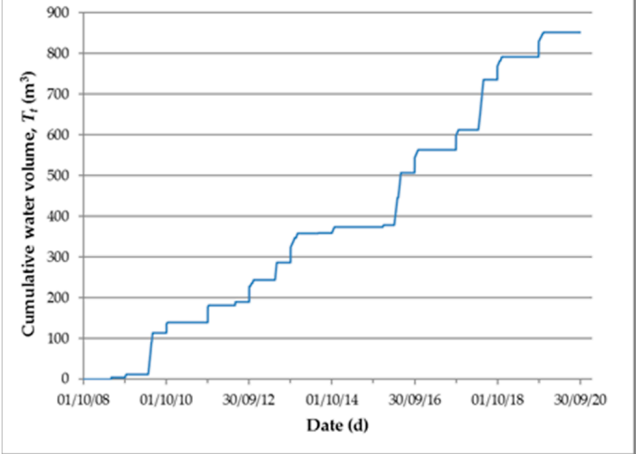

(d)

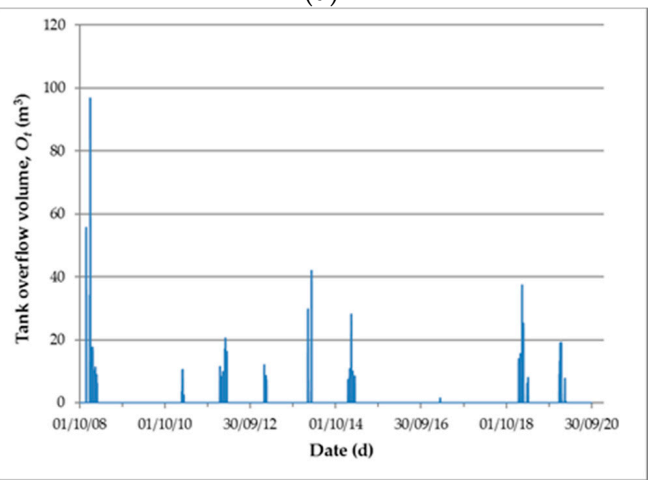

(f)

Figure 9. Stored water volume in covered (a) and uncovered tank (b); cumulative water volume supplied from other sources to meet the water needs of a tomato crop for covered (c) and uncovered tank (d); and overflow water volume from covered (e) and uncovered tank (f) as computed by applied the daily water balance method for tank size $V_{\text {tank }}=167 \mathrm{~m}^{3}$ and collection area $\mathrm{A}=1000 \mathrm{~m}^{2}$. 


\section{Conclusions}

The greenhouse agriculture type has a huge potential to harvest rainwater with a low level of investment, but the level of adoption of the RWH technique is very low, both in Greece and generally in the world. Studies on this potential are missing, as well as on the required tank size.

In an effort to fill that gap, reliability analysis of rainwater harvesting tanks used to meet water needs of vegetable (tomato) and ornamental (begonia) crops cultivated in greenhouses in two regions of Greece with significant greenhouse areas and low annual rainfall was performed.

In the case of begonia crop, covered tanks that ranged from 100 to $200 \mathrm{~m}^{3}$ per $1000 \mathrm{~m}^{2}$ greenhouse area had a reliability coefficient ranging from $65 \%$ to $72 \%$, respectively, to meet the water needs of plants during a 12-month cultivation period.

In the case of tomato crops, covered tanks with volumes that ranged from 100 to $290 \mathrm{~m}^{3}$ per $1000 \mathrm{~m}^{2}$ of greenhouse area had a reliability coefficient of $90 \%$ to $100 \%$, respectively, while uncovered tanks had a maximum reliability coefficient of $91 \%$ for a critical tank volume of $177 \mathrm{~m}^{3}$ per $1000 \mathrm{~m}^{2}$ of greenhouse area during an 8-month cultivation period.

Overall, both covered and uncovered rainwater tanks can be used as alternative sources of available water to meet the irrigation needs of greenhouse crops. Required tank sizes seem affordable, and their use could ease the local pressures on water resources.

The next steps require a search on tank sizing for other cultivations and regions as well as a financial investigation of relevant investments.

Author Contributions: Conceptualization, P.A.L.; methodology, P.A.L., I.-E.K., N.T., A.T.T. and N.D.; software, P.A.L., I.-E.K. and N.T.; formal analysis, P.A.L., I.-E.K. and N.T.; investigation, P.A.L., I.-E.K. and N.T.; resources, P.A.L., I.-E.K., N.T. and A.T.T.; data curation, P.A.L., I.-E.K., N.T., A.T.T. and N.D.; writing-original draft preparation, P.A.L.; writing—review and editing, P.A.L., I.-E.K., N.T., A.T.T. and N.D. All authors have read and agreed to the published version of the manuscript.

Funding: This research received no external funding.

Conflicts of Interest: The authors declare no conflict of interest.

\section{References}

1. König, K.W.; Sperfeld, D. RainwaterHarvesting-A global issuematures. Fachver. Betr. Regenwassernutzung Dispon. 2007, 25, 2015.

2. Angelakis, A.N. Evolution of rainwater harvesting and use in Crete, Hellas, through the millennia. Water Sci. Technol. Water Supply 2016, 16, 1624-1638. [CrossRef]

3. Yannopoulos, S.; Giannopoulou, I.; Kaiafa-Saropoulou, M. Investigation of the current situation and prospects for the development of rainwater harvesting as a tool to confront water scarcity worldwide. Water 2019, 11, 2168. [CrossRef]

4. $\quad$ Campisano, A.; Butler, D.; Ward, S.; Burns, M.J.; Friedler, E.; DeBusk, K.; Fisher-Jeffes, L.N.; Ghisi, E.; Rahman, A.; Furumai, H.; et al. Urban rainwater harvesting systems: Research, implementation and future perspectives. Water Res. 2017, 115, 195-209. [CrossRef] [PubMed]

5. Londra, P.A.; Theocharis, A.T.; Baltas, E.; Tsihrintzis, V.A. Optimal sizing of rainwater harvesting tanks for domestic use in Greece. Water Resour. Manag. 2015, 29, 4357-4377. [CrossRef]

6. Thamer, A.M.; Megat-Johari, M.M.; Noor, A.H.G. Study on potential uses of rainwater harvesting in urban areas. Presented at Rainwater Utilization Colloquium, NAHRIM Mini Auditorium, Seri Kembangan, Malaysia, 19-20 April 2007.

7. Velasco-Munoz, J.F.; Aznar-Sanchez, J.A.; Batlles-delaFuente, A.; Fidelibus, M.D. Rainwater harvesting for agricultural irrigation: An analysis of global research. Water 2019, 11, 1320. [CrossRef]

8. Singh, K.G.; Sharda, R.; Singh, A. Harvesting rainwater from greenhouse rooftop for crop production. Agric. Res. J. 2019, 56, 493-502. [CrossRef]

9. Boyaci, S.; Kartal, S. Rainwater harvesting on greenhouse roof and use in irrigation. Int. J. Res. -Granthaalayah 2019, 7, 93-100. [CrossRef]

10. Hellenic Ministry of Development. Plan for Water Management; Hellenic Ministry of Development: Athens, Greece, 2003.

11. Hellenic Statistical Authority. Annual Agricultural Statistical Survey, Table 3b. 2018. Avaliable online https://www.statistics.gr/ el/statistics/- / publication/SPG06/2018 (accessed on 6 May 2021).

12. Official Gazette of the Hellenic Republic. Part B, No 2055. Ministerial Decision, 5656/18-09-2015; Official National Printing House of Greece: Athens, Greece, 2015.

13. Fewkes, A.; Butler, D. Simulating the performance of rainwater collection systems using behavioural models. Build. Serv. Eng. Res. Technol. 2000, 21, 99-106. [CrossRef] 
14. Ghisi, E.; Ferreira, D.F. Potential for potable water savings by using rainwater and greywater in a multi-story residential building in southern Brazil. Build. Environ. 2007, 42, 2512-2522. [CrossRef]

15. Imteaz, M.A.; Shanableh, A.; Rahman, A.; Ahsan, A. Optimisation of rainwater tank design from large roofs: A case study in Melbourne, Australia. Resour. Conserv. Recycl. 2011, 55, 1022-1029. [CrossRef]

16. Palla, A.; Gnecco, I.; Lanza, L.G. Non-dimensional design parameters and performance assessment of rainwater harvesting systems. J. Hydrol. 2011, 401, 65-76. [CrossRef]

17. Campisano, A.; Modica, C. Optimal sizing of storage tanks for domestic rainwater harvesting in Sicily. Resour. Conserv. Recycl. 2012, 63, 9-16. [CrossRef]

18. Campisano, A.; Modica, C. Regional scale analysis for the design of storage tanks for domestic rainwater harvesting systems. Water Sci. Technol. 2012, 66, 1-8. [CrossRef] [PubMed]

19. Sample, D.J.; Liu, J. Optimizing rainwater harvesting systems for the dual purposes of water supply and runoff capture. J. Clean. Prod. 2014, 75, 174-194. [CrossRef]

20. Tsihrintzis, V.A.; Baltas, E. Determination of rainwater harvesting tank size. Glob. Nest J. 2014, 16, 822-831.

21. Londra, P.A.; Theocharis, A.T.; Baltas, E.; Tsihrintzis, V.A. Assessment of rainwater harvesting tank size for livestock use". Water Sci. Technol. Water Supply 2018, 18, 555-566. [CrossRef]

22. Guo, Y.; Baetz, B. Sizing of rainwater storage units for green building applications. J. Hydrol. Eng. 2007, 12, 197-205. [CrossRef]

23. Cowden, J.R.; Watkins, D.W., Jr.; Mihelcic, J.R. Stochastic rainfall modeling in West Africa: Parsimonious approaches for domestic rainwater harvesting assessment. J. Hydrol. 2008, 361, 64-77. [CrossRef]

24. Basinger, M.; Montalto, F.; Lall, U. A rainwater harvesting system reliability model based on nonparametric stochastic rainfall generator. J. Hydrol. 2010, 392, 105-118. [CrossRef]

25. Chang, N.; Rivera, B.J.; Wanielista, M.P. Optimal design for water conservation and energy savings using green roofs in a green building under mixed uncertainties. J. Clean. Prod. 2011, 19, 1180-1188. [CrossRef]

26. Aladenola, O.O.; Adeboye, O.B. Assessing the potential for rainwater harvesting. Water Resour. Manag. 2010, $24,2129-2137$. [CrossRef]

27. Ghisi, E. Parameters influencing the sizing of rainwater tanks for use in houses. Water Resour. Manag. 2010, $24,2381-2403$. [CrossRef]

28. Palla, A.; Gnecco, I.; Lanza, L.G.; La Barbera, P. Performance analysis of domestic rainwater harvesting systems under various European climate zones. Resour. Conserv. Recycl. 2012, 62, 71-80. [CrossRef]

29. Hellenic National Meteorological Service. Available online: http:/ /www.hnms.gr/emy/en/climatology/climatology (accessed on 25 August 2021).

30. Mitchell, V.G.; McCarthy, D.T.; Deletic, A.; Fletcher, T.D. Urban stormwater harvesting-Sensitivity of a storage behaviour model. Environ. Model. Softw. 2008, 23, 782-793. [CrossRef]

31. Campisano, A.; Modica, C. Appropriate resolution timescale to evaluate water saving and retention potential of rainwater harvesting for toilet flushing in single houses. J. Hydroinform. 2015, 17, 331-346. [CrossRef]

32. Kinkade-Levario, H. Design for Water Rainwater Harvesting, Stormwater Catchment and Alternate Water Reuse; New Society Publishers: Gabriola Island, BC, Canada, 2007; p. 38.

33. Chartzoulakis, K.; Michelakis, N. Influence of different irrigation systems on greenhouse tomatoes. Acta Hortic. 1988, 228, 97-104. [CrossRef]

34. Chartzoulakis, K.S. The Irrigation of Crops; AgroTypos Publishers: Athens, Greece, 2019; pp. 384-385. (In Greek)

35. Londra, P.A.; Paraskevopoulou, A.T.; Psychoyou, M. Evaluation of water-air balance of various substrates on begonia growth. HortScience 2012, 47, 1153-1158. [CrossRef]

36. Hellenic National Meteorological Service. Available online: http:/ /www.emy.gr/emy/el/agriculture/agriculture_city?poli= Tympaki (accessed on 6 May 2021). 